\title{
Defining Financial Strategies of an Enterprise at Times of Crisis
}

\author{
Prof. dr. sc. Goran Kutnjak \\ Dejan Miljenović \\ Matija Radović \\ University of Rijeka, Faculty of Economics \\ goran.kutnjak@efri.hr
}

DOI:10.5901/mjss.2014.v5n19p553

\begin{abstract}
Numerous crises through history have showed different effects on economies, from ones tied to monetary expansion in Great Britain in 1825 to crises caused by oil shocks in the 1970s and 1980s. Every one of those represents contraction, a downward trend in business cycles, which by its features is never the same. With every crisis, and especially the latest one (from 2008 until today), it was observed that business cycles are appearing more often, last longer and have more severe consequences on the economy. Therefore it is of special interest for financial markets and enterprises, which obtain their funds on them, to analyze business cycle movements and creating the appropriate business strategy and financial structure. The readiness of enterprises for the downward phases of the economic cycle, followed by the changes in the financial sector, should be defined by appropriate business strategy. Business cycles for enterprises represent a test of their strengths and weaknesses. A large portion of enterprises after the current crisis will no longer exist, but those which will successfully manage their financial structure, following the business cycle movements, will be ready to enter another period of growth and development. In the frameworks of this paper the structure of financial markets in Croatia is researched as well, as a result of the transition process, through which we got a larger choice of modern forms of financing and investment. The existence of an appropriate number of financial instruments needed for creating supply on the financial and capital market tends to follow the development of needs on the domestic business, private and public sector. Although modest, the domestic stock market shows the ability of creating wanted effects during investing, and special attention require public offers for buying stocks.
\end{abstract}

Keywords: Crisis, Business Cycles, Financial Strategy, Enterprise

\section{Business Cycles - Theroies, Variables, Predictions}

Interpreting business cycles comes down to oscillations in national production (including reduction of employment, etc.) what results in crisis, usually of specific sectors. Regardless of the differences in certain theories, changes in certain key variables, as well as predictions of business cycles, it is possible to predetermine future situations on the economic and financial market, and also the position of a certain enterprise - regarding the circumstances in the financial market, condition of financial burden of the enterprise, and future returns. The correlation of business cycles and cycles of the enterprise is undoubted, since it is a cause-and-effect relationship.

\section{Theories of business cycles}

The formation of business cycle theories began during the 1825 economic crisis and from the beginning they were followed by different thoughts of economists (Mitchell, 1928:3). The different attitudes became more obvious as more and more economists were included into the discussion. For example, Marx (2009:85) thinks that the capitalistic production for many reasons goes through different periodic cycles, going from standby, growing recovery, progress, satiation, crisis, and stagnation, while Samuelson and Nordhaus (2005:468) define business cycles of the economy as omnipresent fluctuations in the total national production, income, and employment that last from two to ten years and are characterized by wide expansion or crisis most of economic sectors. Pushing each cycle are two basic phases - expansion and recession, which alternate each other, but we should acknowledge the fact that not every cycle is the same by its duration and effects. Romer $(2006: 174)$ thinks that the basic feature of fluctuations is that they do not occur under any simple or repeating pattern, and phases of business cycles can be encouraged by different economic conditions, technological innovations, and political changes that lead to a unsuspected twist in monetary or fiscal policy. 


\section{Variables of business cycles}

The complexity of influences is expressed by simultaneous actions of a large number of factors that affect the aggregate supply and demand. Since the interaction of aggregate supply and demand form macroeconomic variables like real GDP, employment and unemployment, price and inflation, and foreign trade, this interaction affects the formation of business cycles (Samuelson and Nordhaus, 2005:415). Sudden changes in the direction of these variables can occur for a number of different reasons and represent the unpredictability of business cycles characteristic for market economies. Thereat we differ between external (exogenous) and internal sources of business cycles. Exogenous sources form outside of the economic system (wars, scientific and technological discoveries). Internal sources are created by mechanisms within the economic system. According to this approach every blossom births recession and crisis, and every crisis brings recovery and expansion in regular periods that are repeated (Samuelson and Nordhaus, 2005:469-470). Such principles of business cycle movements always represent new conditions to which they have to adjust.

The existence of different business cycle theories, there are different variables that affect them. Thus differ cycles that form due to shocks of aggregate demand and effects of the multiplier-accelerator model, expansion and money and credit crisis, price and labor supply movements, productivity shocks in a single economic sector, and aggregate supply shocks. Keynes (1987:181) refers to such variables underlining the basic characteristics of a business cycle, mostly caused by fluctuations in marginal efficiency of capital with the needed fluctuations of investments, interest rate movements, and changes in the propensity to consume that leads to fluctuations in employment. Accordingly, we can conclude their actions are related to financial market cycles, credit cycles through which businesses go through in their operations, like their investment, production, and life cycles. Changes in influential variables of business cycles create a need for a continuous tracking of participants in economic activities.

\section{Predictions of business cycles on the financial market}

Every movement of the financial market affects it on two levels - macro and micro level. Mendoza and Terrones (2008:2) in their paper review the credit expansion on those two levels. Macroeconomic data show a systematical relation between credit and economic expansion, rise in real estate prices, growth of external deficit and exchange rate management. Microeconomic data indicate a strong connection of credit expansion and financial structure of an enterprise, its value, external sources of financing, and indicators of banking sensitivity. Undoubtedly, on the financial market, there are cycles that affect the overall macroeconomic business cycle. Although the formation of these cycles cannot be completely predicted, there are predictions regarding future returns, as well as expectations. Bacchetta, Mertens, and Wincoop (2009) have determined there is a significant predictability of returns on the international trade market and the stock and bond market. Also, they determined that on a market where returns are hard to predict, on the money market, it is also not possible to predict errors in predicting. Therefore the predictions of returns on financial markets are tightly connected to explanations of prediction errors. Predicting financial market movements also depends on monetary policy created by the national bank. Interest rate movements that determine capital availability and investment realization completely depend on policies of these institutions. Thus, justifiably, measures taken by national banks are closely watched because they potentiate future economic movements. It is hard and basically impossible to take into account all macroeconomic long-term and short-term variables that influence financial movements. But, it should be kept in mind that the legalities of financial markets are subordinated to their purpose to efficiently allocate savings to end users - enterprises, state, and population. The latest economic crisis, according to its symptoms, was hard to predict on certain national markets. Surprisingly, it successfully moved from USA onto the world economy. Longtime globalization and liberalization of international economic sectors took its toll and partly made such chain reaction possible. During the recession economic conditions were violated, security and faith in markets is lost and they become unstable. Constant changes in interest rates, reduction of spending and production completely change the investment and business policy of all participants of the financial market, especially those of enterprises. In order to predict such movements it is important to highlight that, besides the business cycles, there are cycles within the financial market itself. We can talk about credit cycles (Mullineux, 2002), implying increases and reduction of the will to borrow, that maintains cyclical movements of the interest rate forced by the monetary government and which is connected to business or economic cycles.

\section{Business cycles and cycles within an enterprise}

Like macroeconomic and credit cycles, within an enterprise certain cycles are also occurring, but on a micro level. We can talk about production cycles, time cycles of stock turnover, generally about the days of short-term and long-term asset turnover, sales cycle, and, in marketing, the life cycle of products is constantly being analyzed and measures are taken for its survival. These cycles have their laws, and sometimes, as is the case with the life cycle of an enterprise, they coincide with macroeconomic cycles. Life cycles of an enterprise can be prolonged through a strategy of merging and annexation, 
by widening the market segment, by building better relations with consumers and encouraging consumption through a thoughtful price policy. Overall, an enterprise, within its organization, can implement cost reduction policies (by closing non-profit business sectors or product lines). However, even those measures cannot provide security of continuous operations and maintaining liquidity.

In long-term, what can contribute to survival in times of crisis are basic changes that form by using new technologies, scientific and technological development, using intellectual and renewable sources and innovation (Sadtchenko, 2005). Of course, all enterprises are under the influence of macroeconomic movements, especially long processes of liberalization and integration, but we cannot forget the influence of enterprises as economic units on the economic environment, and the activities of their production, investment, and other cycles.

\section{Role of Expectations on Financial Markets and Correlation with Economic Fluctuations}

Expectations are tied to all markets, and since the current crisis began on the financial market and left the biggest consequences on it, it also deserves special attention - especially in times of announcing global economic recovery, or rather the beginning phase of a new business cycle.

In previous years economic growth unfolded in the context of a lower price of capital, rising confidence in financial institutions, growth of available external sources of financing, and growing value of collateral. Today, a question of sustainability of that process arises. Expectations on financial markets are significant in predicting and creating future economic environments. They are an economic phenomenon and are a subject of discussion of all great economists like Keynes (1987), who looked at them as determinants of production and employment. In developed financial markets expectations are mostly tied to movements of stock and bond prices. Therefore, expectations firstly are dependent on the level of development of a national economy and associated financial market, general macroeconomic variables, monetary and fiscal policy of a country. Expectation is an indispensable companion of every business investment. Expectations, or, as they are often called, speculations, are characteristic for investments in market economies. They are tied to risk of investors and their endeavor to realize the option in which the risk will be smaller. Samuelson and Nordhaus (2005) say risk refers to variability of return on investment. Unfortunately, investments with a low level of risk bring a low rate of return. Some investors invest based on data from financial reports of enterprises, while others try to decipher the psychology of the market and create adequate expectations. Such behavior is present in conditions of economic growth when positive business movements make securities of enterprises, state, and financial institutions very attractive for purchase. Often investors disregard logic because of panic caused by speculation, after which comes the disappointment because of a drop in value. When such psychological hysteria covers the market, they form so-called bubbles and breakdowns (Samuelson and Nordhaus, 2005:522). Sometimes worthless stocks (because of future expectations) get new value. Such movements of stocks are rational speculative bubbles, which means financial investors can act rationally as long as the bubble is growing. Investors holding the stocks in the moment when the bubble bursts (suffering great loss) can be rational if they realize there is the possibility of a breakdown, but also that the bubble will continue to grow. In that case, they could sell their stocks at a higher price (Blanchard, 2005:326). Causes of forming such bubbles depend on the type and activities on the market. Mulineux (2002) thinks that business cycles in Japan, South Korea, Southeast Asia, and USA arise because of excessive investment into plants, financial assets, and real estate markets - what leads to the creation of bubbles. Positive expectations sometimes significantly contribute to creation of additional positive conditions in the phase of economic, and therefore financial expansion. If they are severely expressed by excessive investment, they can create bubbles that do not reflect the real state on the market. Before the symptoms of recession, expectations can point to that by noticing certain negative movements, which would usually be disregarded. In the current phase of global economic crisis all expectations are directed towards a quick economic turn that leads to growth followed by financial recovery. Such expectations already create additional effects for business activities that would appear in the phase of growth.

A number of factors can form expectations on the field of finance and they are not characteristic just for certain investors. Institutions like national banks, brokerage firms, investment funds, and private investors are looking to predict future movements in order to plan its investments. According to Blanchard (2005) one of the basic features of expectations is creating whims that cause deviation of the stock price from their intrinsic value. Within it, the basic question of the theory of expectations on financial markets is contained: "In what measure can stock price movements be attributed to a rise in intrinsic value of a company's stock as a result of its good operations?" How important are expectations of market participants in modern macroeconomic and business analysis says the fact that even psychologists are dwelling with the hysteria or panic on the market caused by good or bad news. Market regulation enters deep into the socio-economic area and understanding of human development in order to understand market activities better (Urban, 2008). Unlike certain economic variables that can be safely managed, expectations do not fall under economic legalities and present "an element of surprise". From the macroeconomic level they create positive and negative effects like speculative bubbles that (if they 
last) can lead to significant contractions in the business cycle. An example of natural compatibility of new information that can affect expectation and the market is showed in the model of market efficiency. According to certain comprehensions expectations on efficient markets will not have an effect until they are proven correct and coincide in time with an element of surprise or information on the market. Even then there is a possibility of sudden changes that cannot be foreseen. Such changes are hard to implement into expectation mechanisms on the market. However, for the expectations not to be taken as plain and negligible guessing, numerous institutions and enterprises implement them into their own business policy. An example of implementing expectations into some mechanisms is predictions of the central bank of how a certain measure or operation will reflect on the market. It is impossible to completely neglect the influence of expectations on any market, because future business and investment policy depends on it. Analogously expectations must be an integral part of business and investment strategy of every individual, enterprise, and the entire market.

Development of financial markets is conditioned by ability of capital to move freely and to create a needed security of return on investment. Flow of capital on the financial market, because of influences on economic growth and development, are followed by appropriate fluctuations of that market. According to Van Horneu (1997:551) the purpose of financial markets in an economy is to efficiently allocate savings for end users. For this purpose a number financial intermediaries like banks, insurance companies, pension funds, mutual funds, and resellers of financial instruments like mortgage loans have been created (Samuelson and Nordhaus, 2005). Some flows or transactions go directly to financial markets, while others go through financial intermediaries. The financial market represents locations, individuals, instruments, techniques, and flows that make mediation of cash surplus and shortages, or money, capital, and foreign currencies. Underdeveloped financial markets are reduced to deposits, loans, and banks. Developed markets have an abundance of financial instruments, diverse financial institutions, complex financial techniques, and numerous financial flows. In practice there are numerous markets: stock, bond, state securities, loan, option and future markets, credit card receivables market, leasing operations, export receivables. Together they form a unique financial market (http://limun.hr/main.aspx?id=17065). Financial markets, intermediaries, and instruments form a financial system whose basic function is connecting savings and investments of following sectors (Van Horne, 1997:553): 1) households, 2) non-financial enterprises, 3) states, and 4) financial institutions.

The importance of business cycle influences manifests in four basic functions of the financial system (Samuelson and Nordhaus, 2005:503): 1) transfer of resources through time, sectors, and regions, 2) economy risk management, 3) collecting and sharing cash funds, and 4) execution of the clearing role. Without these functions there is no possibility of economic growth and development and therefore they are the foundation for performing business cycles. Funds on the financial markets are not always available to the same extent because of different division of money supply in national sectors, from state and enterprises to banks. Banks as financial intermediaries that supply enterprises, investors, and state with money, by getting loans or buying government bonds, depend on the supply of primary money that is controlled by the central bank. According to Blanchard (2005:86) with such control, a balance between supply and demand for primary money is achieved, which, in final, affects the interest rates. The ability of the central bank to form interest rates is only one of the elements that influence the business cycle in which is the economy. By creating general conditions for business bank operations on the financial market, the central bank, though them, forms interest rates and loan availability. For economic fluctuations it is important for such operations to have an end effect on the aggregate demand that, in interaction with aggregate supply, creates favorable or adverse conditions on real production, employment, and inflation. Operations of financial institutions and the national bank can be encouraged by a government intervention. If such intervention is not in accordance with the natural business cycle formations, it can cause anti-cyclical movements of macroeconomic variables like price level, production, and unemployment (Friedman, 1992:47). Modern financial markets ensure attractiveness with numerous financing options, investment options, and banking services that are continuously developing. Risk management that follows such activities depends on insurance mechanisms without which negative consequences for investors could occur. Since a certain level of risk always follows investments, a special consideration is needed for those risks that come from a downward phase of a business cycle. Additional conflict in business cycle operations and functioning of the financial market comes because financial markets in the capitalistic economic model enjoy a certain level of unlimited time in the form of speculations regarding future investments and returns. Efforts of financial markets to ensure long-term positive effects sometimes overlap with downward phases of the economic cycle. However, even on these markets there are ups and downs, so we can speak of cycles of financial market activities.

\section{The Role of Financing and Influence of the Business Strategy on (Financial)) Sustainabitity of an Enterprise in Times of Crisis}

According to Gulin (2009:329) money management is one of the most important functions in times of crisis. It is largely tied to the business operation financing strategy, but it depends on the realization model and strategy as well. It is 
impossible, in times of crisis, to completely leave this strategy to the CFO, but rather the question of financing and money management is an obligation of the whole management team.

If we start from the basic assumption is a unique financial system then its sources of financing are looked as a base on which this system rests upon. Finances are crucial for: 1) founding the enterprise, 2) current operations, and 3) enterprise development.

Enterprises in Croatia, for achieving said functions, have different forms of short-term and long-term sources of financing available, which can be realized from own or someone else's sources. Also, we differ internal and external sources. Therefore, in the area of own external sources, a dominant forms are issuing securities like stock and bonds, and short-term and long-term borrowing of funds from the banking sector. Of course, when issuing securities, a company must take into account the real market value and business position of the company. Attractiveness of issued securities depends solely on these elements. Except from regular operations of the company, sources for financing growth and development can be achieved by borrowing someone else's capital, most often from banks. One should bear in mind the golden banking and balance rules of financing, which are the basis for long-term stability of the financial structure of every enterprise (Marković, 2000). About the importance of the relation between own and other's sources of financing, speaks the fact that growth of the company will depend on it. Excessive use of other's funds like bank loans requires larger payments in the form of interests. Interests are an expense that reduces future value that is expected by investment realization. Depending on the relation of own and other's sources of financing, enterprises can choose between (Gulin, 2009:329): 1) balanced, 2) slower, or 3) faster growth than balanced.

Required funds can be realized in the form of long-term and short-term bank loans, which, for their issuing, set certain conditions, like creating and proving the sustainability of the investment program. Company's need for money condition the business activity in the banking sector and makes the largest portion of their activities of issuing money funds, next to loans to individuals. The ability to ensure the right amount of credit mass, where banks only have the role of intermediary, for the business sector depends on the monetary policy, which is formed according to the activities of certain macroeconomic variables in every business cycle.

At times of a downward business cycle phase (due to reduced demand and difficult access to banking market funds) companies are encountering a problem of financing and maintaining liquidity and solvency. Basic problems with which companies are encountering as a consequence of the current crisis are (Osmanagić-Bedenik, 2003:12):

1. Maintaining the ability to pay obligations at any given moment (liquidity principle)

2. Achieving minimal profit or at least meeting the expenses, therefore avoiding unbalanced or excessive losses

3. Creating and maintaining enough success potential

All three factors point to a significant problem of financing in times of crisis that includes the overall liquidity of the company. Popović and Vitezić (2009:425) define liquidity as the ability of unobstructed operations of the business process and meet obligations, which is a special problem of every enterprise in times of financial crisis. On one hand, the company is trying to prolong the payment deadlines for buyers, while, on the other, suppliers insist on a timely collection.

In a recession financially compromised companies get a new basic business goal - survival. Loss of income caused by a lower buying power of consumers in times of crisis is the basic problem of every company. This is when economic conditions change quickly, and previously set business goals of the company are questionable regarding their realization. Insisting on keeping the same financial and strategic pre-crisis structure of the company in times of crisis would mean its quick failure. Therefore, the ability of the company to adjust its financial, organizational, and managerial structure is a determining factor for its survival. The nature of business cycles in a company imposes a need for constant change through which consistency and durability of strategic goals is removed and they can always be reevaluated and improved. Every activity of management in times of economic crisis must be directed towards the future. Predictions and expectations regarding economic recovery must be built into the business decisions. Turning the situation to your advantage in times of crisis is not easy, but there are companies that will base their future growth on radical decisions made in times of crisis. Previously mentioned endeavors of management are a higher level of management in a company, which is called change management. Making changes is necessary, but not enough to ensure future success. Dujanić (2004) emphasizes that changes are needed in order for the company to refocus, reposition, rebuild, reorganize, and think of future operations and development. Competitiveness can solely be achieved by competing and future success of the company will depend more on the differences and readiness for future changes. Such strategic commitment must be strongly backed by an appropriate financial strategy of the company, even in times of crisis. In order to keep a desired level of liquidity in times of crisis enterprises must timely and successfully: 1) rethink short-term and long-term financing and business strategy, 2) ensure 
steady and reliable suppliers, 3) keep and build relations with customers, 4) estimate risks and manage them, 5) reduce unnecessary costs, 6) find new sources of financing within the company (managing money flows).

A large number of enterprises, in order to avoid crisis situations, seeks to implement predictions and expectations regarding business cycles on the financial market into their own business strategies. There are mathematical and econometric models that enable companies to predict crisis based on certain indicators of financing like Altman's Z-factor (Popović and Vitezić, 2009). Such models are especially significant since they are based on the values of financial indicators of a company that could be influenced by the financial crisis. Unfortunately, for most companies, predicting downward phases and big macroeconomic crises like the current crisis is hard and they cannot protect themselves on time. In normal circumstances enterprises would focus most of their operations on ensuring survival because they are not ready for such conditions. This does not mean that the company is quitting market competitiveness and its market segment, but rather the opposite. It must invest additional efforts to ensure their sources of income in order to survive the hard times.

Managing internal activities in a company in times of crisis is of key importance. According to Kropfberger (2009) unpredictable influences of the environment represent only $20 \%$, and internal problems in an enterprise $80 \%$ of crisis cause. They are: 1) insufficient capital, 2) insufficient cash (liquidity problem), 3) mistakes and incompetence of management, 4) obsolete product without innovation, 5) non-competitive cost structure and insufficient cost management.

Good financial manager will know to recognize favorable capital market conditions and get the company the muchneeded funds at favorable conditions. A special task is presented in times of recession, like the current one, when managing the company's money flow is of vital importance for its survival. Loss of income due to a reduced purchasing power of consumers in times of crisis is the basic problem of every enterprise. Situation is further worsened in companies that with quality financial management in the past did not achieve positive effects of investments. There are a large number of companies that by investing into the capital market achieved bad financial standing that are due in times of crisis. It is logical that in times of crisis business environments and economic frameworks are changing and previously set business goals of the company are questionable regarding their realization. Insisting on keeping the same financial and strategic pre-crisis structure of the company in times of crisis would mean its quick failure. Therefore companies must adapt their organizational, financial, and management structure which is key for their survival. The nature of business cycles in a company imposes a need for constant change through which strategic goals must always be reevaluated and improved.

In times of recession survival of the company is set as an additional short-term or medium-term objective (depending on the length of the crisis). Importance of harmonizing business strategy defined by mission and goals of the company with financial strategy is the basic key to success. Financial manager must know how to successfully back quality business activities of managers with quality funds on all hierarchy levels. A quality financial manger in case of bad decisions of the chief manager will know how to balance the loss and the gain. For all enterprises the function of controlling, often performed by financial managers or the director, is of great importance. Good basic elements of controlling enable that the of company management efforts are successfully focused on achieving set goals. As in other business functions, marketing seeks additional efforts (especially for keeping consumers, and attracting new ones) in times of crisis. Quelch and Jocz (2009) emphasize that there are no two identical business crises and each demands the use of different marketing measures. During recession consumers reduce their consumption, income of the company drops and that is why it needs to cut costs, reduce prices, and postpone new investments. However, cutting costs on marketing might prove to be a mistake. Stopping investments into company brands and consumer need research in the long run could endanger business.

Said endeavors of management are part of a higher level of management in an enterprise, which is called change management. Predicting future economic conditions fits into main determinants of the company's strategic policy. Financial crisis does not only seek changes of the financial structure, but the overall organization of the company and its business policy. A crisis is a chance to make changes that are necessary for the company, and remove weaknesses that, under normal operating conditions, would not be noticed. Dujanić (2004) emphasizes that changes are needed in order for the company to refocus, reposition, recover, reorganize, and think of new operations and development. Competitiveness cannot only be achieved by competing, but also by readiness for future changes. Such strategic commitment must be argued by an adequate financial strategy of the company - even in an economic crisis.

\section{Effects of Bisiness Cycles and Expectations on the Croatian Financial Market}

The structure of the financial market in Croatia is a result of a transition process through which a greater choice of modern forms of financing and investment arisen. Existence of an appropriate number of financial instruments, needed for creating supply on financial and capital markets, seeks to keep track with the development of needs on the domestic private 
and public sector. Although modest, the domestic securities market shows desired affects with investments, and special attention bring public offers to buy shares.

Movements of the domestic financial market are currently revolving in the conditions of a downward trend of the global business cycle. It should be emphasized that the domestic financial market does not have the characteristics of developed western financial markets; it is medium developed and in the frameworks of available financial instruments is not lagging behind other European markets. Financial market, especially the banking sector, offers a number of financing options to all domestic economic entities.

In accordance to Croatian government policy, in which the backbone of the economy is free entrepreneurship, the banking sector offered appropriate forms of financing this sector. Crediting of small and medium entrepreneurship has been contracted with most domestic banks and financial institutions. The importance of such financing comes from the fact that small and medium entrepreneurship has been promoted as the foundation of domestic economic growth for years. Every entrepreneur in the beginning of its operations must invest certain funds into the business he is starting. If he does not have his own funds, he will have to borrow it, because he will not be able to start a business project and contribute to creating a greater national product. Therefore, the role of loan banks in forming global business cycles through encouraging economic growth is undoubted.

Also, it is necessary to consider risks included in credit exposures that can realize at the bottom of the current business cycle and create additional negative consequences. In order to understand the influence of the banking sector on business cycles, it is important to understand the term financial accelerator. Mishkin (2008) states that the problems on the financial market can overflow onto wider economy and have negative effects on production and employment. Negative effects on production and employment will have a rebound effect on prices of assets and, in a way, create a closed circle in which financial problems will limit economic activity. Such situation leads to higher uncertainty and increase of financial problems, as well as a decrease in macroeconomic activity. In scientific literature this phenomenon is called a financial accelerator, which is connected with the process of credit growth, and its movements in the opposite direction can have negative consequences on loans, and also business cycles. The key elements of financial accelerator actions are income and expenses (spending) of households and companies, since assets and funds with which they have represent insurance in case of failure to settle its liabilities.

\section{Graph 1.Sector distribution of bank loans in Croatia}

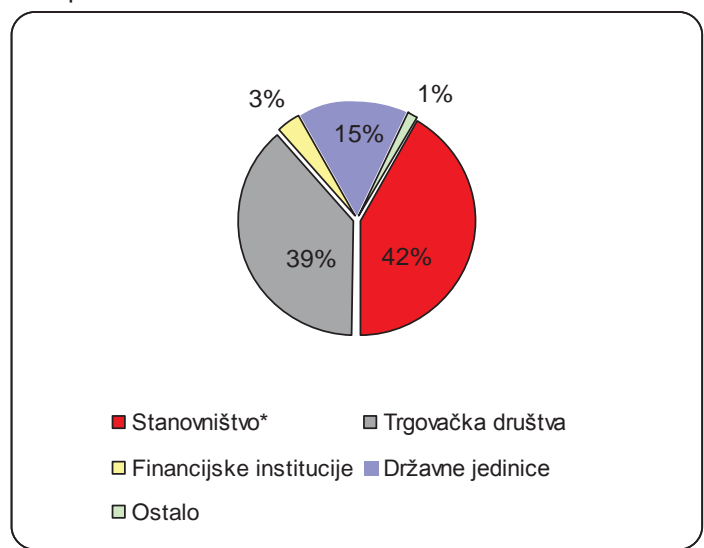

Source: Croatian National Bank, Standard presentation format, 2. Trimester 2014

According to Graph 1 households and companies are the biggest users of distributed bank loans in Croatia (on $31^{\text {st }}$ of December, 2013). By placing the largest portion of money funds to the population (42\%) and companies (39\%) domestic banks ensured a basis for keeping further domestic spending, although in a smaller amount. In reflection, in 2005 the population got $49,7 \%$, and companies got $39,9 \%$ of loans (HUB Analysis, 2007). Financial accelerator of domestic business cycle reflected the reduction of prices of assets with higher interest rates on housing loans, and therefore decreasing the demand for real estate and activities in the construction sector, thus contributing further slowdown of the national economy.

When analyzing the effects of the crisis on the Croatian financial market we need to differ the American and European character of general financial, and then banking market and securities market. In USA it is based on very developed trading of securities on capital markets. In Europe, as well as Croatia, the credit character of the market is more developed in 
regard to the needs of the civil and business sector. Expectations regarding the domestic securities market refer to the companies whose stocks are traded on the stock market, but also the credit terms of banks regarding future investment options. However, besides the movements in securities value on the market, of key importance is for every company on the credit market, as a part of the financial sector, to have access to needed investment funds. Thus banks in the domestic financial system are important intermediaries that, with availability of funds, decide the rhythm of performing economic activities.

Reactions of the Croatian financial market to the global economic crisis are tied to operations of foreign bank branches. Happenings in their European centers influenced the credit policy of these branches in Croatia. When the possibility of bankruptcy of numerous big European banking groups became very certain, European governments made different possibilities of nationalization. Today as well, government assistance to foreign banks enables them to survive the economic crisis. But, besides, branches of those banks in Croatia result in multi-year business results with significant profits and despite the recession, they operate more or less very good or excellent. This is an indicator that the Croatian banking market is still profitable and, accordingly, should be interesting to investors - even in times of recession.

The most severe reaction (for citizens and enterprises) in the banking sector was an increase in interest rates, what reduced the available incomes and potential gain. On the other hand, such increase in interest rates is a great source of business results of banks.

Graph 2. Average active interest rates of banks from 1999 to 2014

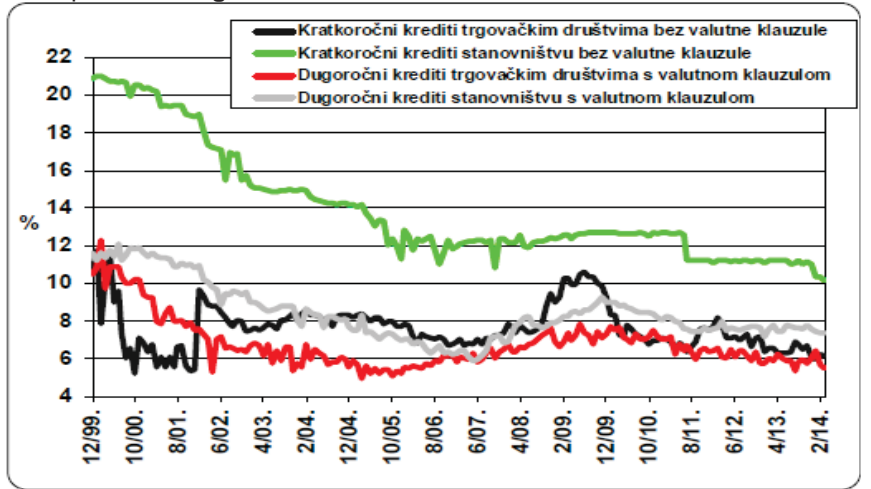

Source: Croatian National Bank, Standard presentation format, 2. Trimester 2014

Graph 2 shows the movements of bank interest rates in the period from 1999 to 2014. Trend of increasing interest rates is present from the culmination of the global crisis in October 2008. It is necessary to show the differences that exist in interest rates of the domestic capital market and those used in the Eurozone (see more: Dragojević Mijatović, 2009). Such movements put domestic economy into a non-favorable position in reflection to economies of the European union since higher interest rates decrease their competitiveness.

Higher interest rates also additionally decrease the income of every indebted citizen in a financially hard period. This is especially reflected in constant rebalancing of the state budget, which significantly influence the available income of those employed in the public sector. Reduction in income of a large number of citizens and a questionable sustainability of state could create negative reactions on the banking market. Enterprises, as well as a large number of citizens, decreased their spending to a minimum. Unless there is growth and development, there will not be a need for investment, and no need for eventual borrowing of funds in the financial sector, especially for enterprises. In Europe, at the height of the crisis, a strong wave of instability and crashing of banks and funds is expected, just like in USA. In that order, there would be a transfer of negative consequences to smaller markets, like Croatian. One of the basic reasons is dominance of foreign bank branches on the domestic financial market. However, it is confirmed that the domestic banking sector is stable even in times of crisis. It is to be expected that money mass management will strongly influence the credit mass, which is a question of monetary policy implemented by the central bank.

If we are talking about activities outside of issuing loans, significance has the securities market. Unlike developed capital markets, the domestic one has low liquidity expressed with the value of turnover on the market. Despite positive movements, an obstacle to further development is still a relatively low liquidity of the market. It is manifested as a lack of stable and high daily turnover, existence of illiquid stocks, and ability to influence the price. Unlike ours, developed capital 
markets are characterized by high liquidity that enables large transactions with a very low influence on the price. Unlike the developed financial markets, we need to also differ the needs of domestic users of numerous financial instruments. In Croatia there is a large number of companies trying to gain their market share with their products and services. Unless these efforts have enough own funds, they use someone else's. Further growth and development will change their organizational, business, and financial structure so their financial needs will be different. If companies ensure their success by issuing their own stocks, they can become very active participants of the capital market, according to their own business, organizational, and market level of development.

A downward trend of the economy received a boost even with the crisis of state budget in which the lack of funds led to many restrictions in the public sector, and therefore in other sectors of the economy as well. Since the expectations on the domestic financial market do not have the character and the nature of those on developed markets, they are watched in the sense of investment policy of the subject that are taking funds for that purpose. Expectations of citizens and companies in Croatia are focused on movements of interest rates in the banking sector, since every expense is further analyzed. This is especially emphasized in times when private and business incomes are decreasing. With highly indebted companies the movements of the interest rates on large loans literally decide about their liquidity. Even though there are differences in functioning and behavior between financial sectors of USA, European union, and Japan in views of ways and areas of investment, the latest crisis, because of its global character, had even influences on their markets. A quick and permanent drop in value of securities on the market followed by a drop in production and demand caused losses of private, banking, but also the public sector because of the limiting of budget spending during the recession.

In Croatia a large portion of expectations is focused on anti-recession measures of government like rebalance of the budget and passing a law on crisis tax (NN, 94/09). Unpopularity of these measures is undeniable, but with a lack of strategic financial policy of the state they are unavoidable. Limiting public spending through measures (like reducing costs of public companies) has significant influence on economic activity. An environment in which most business activities are reduced to a minimum until the crisis effects weaken is created. In such an environment a large portion of business activities is focused on movements and announcements on the global market. Lately, every rise in value on capital markets had a tendency to be seen as a possibility of economic recovery. However, this does not have to be the case, taking into account the nature of expectations that can largely bend the real picture of the financial sector. But, until there is a rise in real production these expectations will not be confirmed, but they are currently helping to create a positive environment. The recent recovery of the capital market is considered the best news. Recovery of stock markets is modest and could be threatened with the slightest negative reaction. Therefore, it is good to form positive expectations directed towards economic recovery. It should be taken into account that in a recession negative effects are expressed with the same force that was present in the previous phase of growth, as if it is a sort of a cleaning of the economy. Economic strength in Croatia will not go back to previous levels with the same pace it fell. Undoubtedly (Žigman, 2009) every time when a domestic economy would record a great drop and entered a recession, in order to recover to the previous level a longer time period is needed - of a few years.

The current non-favorable economic situation in Croatia is a result of a multi-year neglect of domestic strategies of manufacturing, export, and economic development, based and financed solely from loans. The burden of loans will not just disappear, but changes that should appear in forming a long-term policy of economic development must appear now. The current downward phase of global economic cycle showed real imperfections in economies of every country, Croatia included. High foreign debt, relying on results of seasonal tourism, and disincentive fiscal policy are only a few. Undoubtedly, the Croatian economy was in a form of a crisis even before the current economic crisis occurred. Foreign loans for financing capital infrastructural investments show to be somewhat tenable while it is generating positive effects. But, in times of a recession those effects disappear, and there is a problem of regular servicing of debt. However, as this is not enough to create significant disturbances, connecting with macroeconomic variables like opposite spending movements of certain sectors and financial accelerators that appears in finance is needed. In order to achieve long-term stability in the area of remediation of capital investments, in the future, in their implementation, policies of potential business growth or drop must be made. That way, with predictions, the financial sustainability of every project in the hardest of economic periods could be found. Changes in national policy of economic development are necessary in order to achieve long-term positive effects of growth and development. Creating frameworks for building an export oriented economic system is now the primary goal, because the former framework built on debt confirmed itself to be a total miss. It is not enough only to set a legal and fiscal framework but within it implement concrete measures for ensuring future economic and financial development. The current economic crisis is a chance for all Croatian companies to reevaluate their business operative and strategic policies, try to predict in which direction the economy of the region and nearby EU countries will go. Based on such long-term analysis companies will be able to create the basic requirements for a quality form of technological, economic, political, and social progress. Accordingly, the domestic financial sector would adapt and develop parallel to the 
needs of a developing domestic economy, and represent a significant support on the way towards further economic growth. Global and national markets of financial services are going through big changes and it is certain that after the current recession the conditions on it will be completely different than current ones. New groups of investment products, like private investment funds and hedge funds (funds of risky, private capital and futures funds), are attracting more and more investors, shifting the gravitational center on the world capital market (www.deloitte.com). Billing jobs and financial transactions, which are the largest source of income and profit of many financial institutions that are currently in the process of restructuring, which is changing the foundations of banking activities.

\section{Conclusion}

Movements of macroeconomic business cycles are tightly connected with credit expansion and financing terms in market economies. Cyclical movements are characteristic for all macroeconomic variables and, when investing into capital markets or business activities, because of risks, must be analyzed. Capriciousness of the financial market caused (or spedup) the downward phase of the current business cycle and led to an economic crisis. Long-term international trade and financial interdependence enabled creation of its global effects. Such movements of business cycles until recently was hard to imagine for world economists, and only a few companies were ready for it. Those who previously implemented into their business strategy the prediction mechanisms and managing the effects of the crisis are now tolerating it more easily.

Microeconomic effects of the current crisis mostly reflect spending of citizens and business activities of a company. Problem of liquidity and insufficient funds caused by reduced spending and difficult access to bank funds cause a financial crisis of a company. In such conditions seeking new sources of funds is diverted from external sources to those within the company. Financial crisis does not only require a change in financial structure, but the whole organizational business system of the company and its business policy. Crisis is a chance to implement changes that are necessary and to remove weaknesses, which in normal operating conditions would not be recognized. Stress is on all segments of the company like human resources, management of costs and income gets a whole new meaning. Measures of managing costs, income, and cash flows are determined by the business strategy in order to influence the financial position of the company. The ability to be different in everyday business activities, innovative with cost reduction, maintaining market segments, and even their increase, in this crisis will differ the winners from the losers. Companies who do not do that are doomed firstly on financial, and then existential demise, which can overlap with the end of the downward phase with another macroeconomic business cycle.

\section{References}

Bacchetta, P., Mertens, E., Wincoop, E. (2009.), Predictability in financial markets: What do survey expectations tell us? Journal of International Money and Finance, No. 28, str. 406-426.

Blanchard, O. (2005.), Makroekonomija, Zagreb: Mate

Dragojević Mijatović, A. (2009.), Kad kažeš kredit, kažeš Hrvatska, http://www.novilist.hr/2009/06/22/kad-kazes-kreditkazes-hrvatska.aspx, (retrieved 09.09.2009.)

Dujanić, M. (2004.), Upravljanje promjenama u poduzeću, Zbornik radova Ekonomskog fakulteta Sveučilišta u Rijeci, Sv. $1,39-51$.

Friedman, M. (1992.), Kapitalizam i sloboda, Zagreb: Školska knjiga

Gulin, D. (2009.), Modeli i metode upravljanja novčanim tokom u uvjetima financijske krize, 44. simpozij Hrvatske zajednice računovođa i financijskih djelatnika, Zagreb: HZRFD

Hrvatska narodna banka (2014.), Standardni prezentacijski format, 2. tromjesečje

HUB Analize (2007.), Stabilnost bankovnog sustava u Hrvatskoj: Gdje se sakrio rizik?, br. 8, Hrvatska udruga banaka: Arhivananalitika

Keynes, J. M. (1987.), Opća teorija zaposlenosti, kamate i novca, Zagreb: Cekade

Kropfberger, D. (2009), Management and Controlling in Times of the Economic Crisis, Faculty of Economics in Rijekai on 4. July 2009.

Marković, I. (2000.), Financiranje - teorija i praksa financiranja trgovačkih društava, Zagreb: RRIFplus

Marx, K. (2009.), Nadnica, cijena, profit, Zagreb: Izvori

Mendoza, E.G., Terrones, M.E. (2008.), An Anatomy Of Credit Booms: Evidence From Macro Aggregates And Micro Data, NBER Working Paper, No. 14049: NBER, http://www.nber.org/papers/w14049.pdf (retrieved 28.05.2014.)

Mishkin, F., S., (2008.), Fleksibilnost monetarne politike, upravljanje rizikom i financijski problemi, Bank of Federal Reservs New Yorka, 11. January 2008., http://www.federalreserve.gov/newsevents/speech/mishkin20080111a.htm (retrieved 26.08.2013.) 
Mitchell, W. C. (1928.), Business Cycles - The Problem and Its Setting, New York: National bureau of economic research

Mullineux, A. (2002.), The business cycle in a globalising new economy: Implications for bank regulation and monetary policy, Journal of Financial Regulation and Compliance, Vol. 10, No. 2, 162-167.

Osmanagić-Bedenik, N. (2003), Kriza kao šansa, Zagreb: Školska knjiga

Popović, Ž., Vitezić, N., (2009.), Revizija i analiza: instrumenti uspješnog donošenja poslovnih odluka, II. izdanje, Zagreb: HZRFD

Quelch, J. A., Jocz, K. E. (2009.), How to Market in a Downturn, Harvard Business Review, April 2009, 52-62.

Romer D. (2006.), Advanced Macroeconomics, New York: McGraw-Hill

Sadtchenko, K (2005.), The pyramidal life cycle of economic structures, Physica A, No. 350, 475.-486.

Samuelon, P. A., Nordhaus W. D. (2005.), Ekonomija, 18. izdanje, Zagreb: Mate

Urban, S. (2008.), Financial markets, expectations and human development, Society and Business Review, Vol. 3, No. 2, 162-171.

Van Horne, J.C. (1997.), Financijsko upravljanje i politika, Zagreb: Mate

Zakon o posebnom porezu na plaće, mirovine i druge primitke (2009.), Narodne novine -službeni list Republike Hrvatske, br. 94.

Žigman, A. (2009.), Čak je i krhak oporavak burzi najbolja vijest u posljednjih godinu i pol, http://www.liderpress.hr/Default.aspx?sid=77600 (retrieved 09.03.2014.)

http://www.deloitte.com/view/hr_HR/hr/pressrelease/fafc718c7cffd110VgnVCM100000ba42f00aRCRD.htm, （retrieved 7.08.2009.)

http://limun.hr/main.aspx?id=17065, (retrieved 14.05.2014.)

\section{Graphs}

Graph 1.Sector distribution of bank loans in Croatia; Croatian National Bank, Standard presentation format, 2. Trimester 2014

Graph 2. Average active interest rates of banks from 1999 to 2014; Croatian National Bank, Standard presentation format, 2. Trimester 2014 